\title{
EFFECTIVE/EFFICACIOUS NONVERBAL COMMUNICATION IN THE CLASSROOM: THE PERCEPTION OF THE NURSING LECTURER ${ }^{1}$
}

\author{
Rosely Kalil de Freitas Castro Carrari de Amorim², Maria Júlia Paes da Silva ${ }^{3}$
}

\footnotetext{
${ }^{1}$ Article derived from the dissertation - The perception of lecturers on the Undergraduate course in nursing regarding their nonverbal communicative behavior in the classroom, presented to the Postgraduate Program in Adult Health Nursing, School of Nursing, Universidade de São Paulo (EEUSP), in 2012.

2 M. Sc. in Nursing. São Paulo, São Paulo, Brazil. E-mail: roselykali1@usp.br

${ }^{3}$ Ph.D. in Nursing. Full Professor at the EEUSP. São Paulo, São Paulo, Brazil. E-mail: juliaps@usp.br
}

\begin{abstract}
This exploratory, descriptive, qualitative and field study aimed to investigate the nursing lecturers' perception of what effective and efficacious nonverbal communication in the classroom is. The study was undertaken in three campuses of a private university in São Paulo, and involved the filming of 11 lecturers, totaling 220 minutes, with a later interview, which was also recorded. As results, two categories appeared: The vision of oneself, with the subcategories Surprise about oneself, Recognizing oneself positively, and Recognizing oneself negatively; and Appropriate nonverbal communication for lecturers, with the subcategories: Giving feedback to the student, Complementing the verbal communication, and Not contradicting the verbal communication. We conclude that the majority of the nonverbal signals emitted by the lecturers was perceived as appropriate, although the need for training in order to identify the nonverbal signs in all their dimensions was perceived.
\end{abstract}

DESCRIPTORS: Nursing. Communication in health. Nonverbal communication. Teaching. Lecturers.

\section{COMUNICAÇÃO NÃO VERBAL EFETIVA/EFICAZ EM SALA DE AULA: PERCEPÇÃO DO DOCENTE DE ENFERMAGEM}

RESUMO: Com o objetivo de conhecer a percepção dos docentes de enfermagem sobre o que é a comunicação não verbal efetiva e eficaz em sala de aula, este estudo exploratório, descritivo, de campo e qualitativo foi realizado em três campi de uma universidade particular em São Paulo, com a filmagem de 11 docentes, que totalizou 220 minutos, e posterior entrevista, que também foi gravada. Como resultados, surgiram duas categorias: Visão de si próprio, com as subcategorias Surpresa sobre si mesmo, Reconhecendo-se positivamente, e Reconhecendo-se negativamente; e Comunicação não verbal adequada para docentes, com as subcategorias Dando feedback ao alunoComplementando o verbal, e Não contradizendo o verbal. Concluímos que a maioria dos sinais não verbais emitidos pelos docentes foi percebida como adequada, sendo, porém, confirmada a necessidade de capacitação para identificar sinais não verbais em todas suas dimensões.

DESCRITORES: Enfermagem. Comunicação em saúde. Comunicação não verbal. Ensino. Docentes.

\section{COMUNICACIÓN NO VERBAL EFICAZ/EFICIENTE EN EL AULA: AUTO- PERCEPCIÓN DEL PROFESOR DE ENFERMERÍA}

\begin{abstract}
RESUMEN: Con el objetivo de conocer la percepción de los profesores de enfermería acerca de lo que es eficaz y eficiente la comunicación no verbal en el aula, este estudio exploratorio, descriptivo y de campo cualitativo se llevó a cabo en tres campus en una universidad privada de São Paulo, con el fusilamiento de 11 profesores, un total de 220 minutos, y posterior entrevista, que también fue registrada. Como resultado, emergieron dos categorías: Información general de sí mismo con las subcategorías Sorpresa de ti mismo, Reconociendo a ti mismo de manera positiva, y Reconociendo usted negativamente, y La comunicación no verbal apropiada para los profesores, con las subcategorías Dar retroalimentación al estudiante, Como complemento a la verbal y No contradice la verbal. Llegamos a la conclusión de que la mayoría de las señales no verbales de los maestros fue percibido como adecuado, siendo, sin embargo, confirmó la necesidad de capacitación para identificar las señales no verbales en todas sus dimensiones.
\end{abstract}

DESCRIPTORES: Enfermería. Comunicación en salud. Comunicación no verbal. Enseñanza. Docentes. 


\section{INTRODUCTION}

Effective and efficacious nonverbal communication, between interlocutors, is considered that which encourages the other to speak, because it demonstrates acceptance and respect; while in inefficacious communication, the interlocutors' behaviors probably weaken the conversation. ${ }^{1}$

Nonverbal communication occurs in personto-person interaction, excluding the words expressed by the same - occurring through gestures, bodily postures, silence, facial expressions, the direction the body is facing, somatic, natural or artificial singularities, organization of the objects in space and even through the relationship of the distance kept by the individuals. It represents approximately $93 \%$ of our communication, as, through studies of nonverbal signals in human communication, undertaken in social psychology, we know that - in an interaction - only $7 \%$ of the meaning is transmitted through words, $38 \%$ is transmitted by paralinguistic signs, and that $55 \%$ is transmitted by body language, hence its importance.

We can classify nonverbal communication by its dimensions, namely: paralanguage, kinesics, proxemics, physical characteristics, factors of the environment and tacesics. The characteristics of each dimension are presented below. ${ }^{1}$ 1) Paralanguage: covers all and any sounds produced by our vocal apparatus, but which do not form part of the sound system of the language that we use; it can demonstrate feelings, characteristics of personality, attitudes, ways of relating with people and self-concept; they are signals that the voice produces, giving rhythm, intensity and intonation to the discourse, as well as grunts such as "ah", "er", "uh", vocal noises of hesitation, tension coughs, sighs etc.; 2) Kinesics is the language of the body, with its movements, and gestures, movements of limbs, nods of the head and facial expressions; 3 ) Proxemics: is related to the use which we make of space, the distance kept between the interlocutors in the relationship, indicating the type of relationship existing between the same, the differences of status, the preferences, the sympathies, and the power relationships; 4) Physical characteristics: are the form and the appearance of our body, which transmits information such as age range, sex, ethnic and social origin, health status, etc., as well as objects that we use and that also demonstrate our self-concept (jewels, clothes, type of car, among others) and the relationships that we keep (wedding and graduation rings, for example); 5) Factors or characteristics of the environment are related to the placing of objects in space, besides the characteristics of the space itself, such as, shape and size; and 6) Tacesics: involves tactile communication, that is, the pressure which is exercised during touch, as well as where the touch occurs and how it is made, besides age, sex, personal space, culture and the expectations of the relationship of the communicators in the relationship. ${ }^{1}$

In interpersonal relationships, nonverbal communication performs four basic functions: it complements, ratifies and reinforces verbal communication; it substitutes the verbal communication; it contradicts verbal communication; and it demonstrates feelings. ${ }^{1}$

Nonverbal communication, in lecturing, although much studied, still lacks more up to date interventionist studies and has been explored in some important aspects such as, for example, one study undertaken with nursing lecturers, ${ }^{2}$ which explored one of the functions of the nonverbal communication: the demonstration of feelings. The above-mentioned study aimed to ascertain if there was a difference in the perception of the students' feelings by the lecturers before and after an explanatory presentation on the issue. In order to achieve this objective, a video was shown to the lecturers, with student nurses, asking them to fill out a questionnaire identifying the feelings shown in the video (the real motives for the presentation were hidden). After the initial instrument had been filled out, a 10-minute explanatory presentation was made, defining the types of communication (verbal and nonverbal) and the functions of nonverbal communication, as well as the feelings, with pictures which illustrated the students' feelings, for better comprehension, and giving examples of some signs which may be observed in the student in the classroom. The video was presented again, with further filling out of the instrument being requested. The results found indicate a difference in this identification of feelings, in general, following the explanatory presentation - that is, the professors identified the students' feelings only after their attention was directed to the nonverbal communication (with the exception of the feeling of fear, which did not change).

Another study ${ }^{3}$ which deserves to be highlighted was undertaken with nurse educators (who, like the nursing lecturers, exercise the role of educators in relation to other members of the nursing team). This study described how a presentation should be prepared, from content through to the 
choice of the audiovisual material and the preparation of the environment, as well as a discourse on the art of facilitation. It was clarified that a good facilitator makes focused questions, challenging issues, listens more than she speaks and serves as a guide for the group discussion. The authors added that the facilitator uses questioning tools, silence and paraphrasing, as well as nonverbal hints. They also emphasized that another essential tool for the facilitator or presenter is her voice.

In the process of teaching-learning, the lecturer performs a fundamental role and, for the learning to occur in an appropriate way, she needs to have dominion over the whole communicative process.

Educators assert that no man is an island: he is communication. In this way, the lecturer cannot place herself in the position of being a superior being who teaches a group of ignorant people, but rather places the self in the humble position of a person who communicates a relative knowledge to others, who possess another relative knowledge. ${ }^{4}$ It is through appropriate communication, making oneself understood and understanding the other in this case the student - through the effective use of her nonverbal communication, that the lecturer has a greater chance of achieving her educational and interactional objectives.

Other educators reflect on the cultural construction of knowledge and on school as having a political commitment with a conservative and innovating character which is also expressed in how this same knowledge is understood, selected, transmitted and re-created. ${ }^{5}$ In relation to the cultural construction of the knowledge, one can assert that without appropriate communication between lecturers and students, that is, without the appropriate use of nonverbal communication, there are serious implications for the construction which can be made of this knowledge and which, inevitably, interferes in the understanding, selection, transmission and re-creation of the same.

It is in the construction of the knowledge, through the lecturer's use of appropriate nonverbal communication, that the entire process of teaching-learning occurs. Learning can be considered an integrated process, in which the person, in their completeness (intellect, affectivity and muscular system) is mobilized organically, this being, therefore, a qualitative process (in which the person becomes better prepared for new learnings, with a structural transformation of their intelligence), and not only quantitative (with a numerical increase of knowledge). ${ }^{6}$
Learning is individual, that is, nobody learns for another, that is to say, the professor cannot oblige the student to learn, as the learning takes place in the student and is undertaken by him, ${ }^{6}$ but the lecturer can motivate the students to the learning through the appropriate use of her nonverbal communication, for example, with an encouraging intonation in her voice, standing closer to the student during questioning, looking at him with interest and facing him, or using gestures which illustrate what she is talking about.

In spite of being widely addressed in the process of teaching-learning in studies which are directed towards the lecturer, ${ }^{2-3}$ towards the student, ${ }^{7-8}$ towards the communicational process as facilitating the teaching and the learning ${ }^{9-11}$ and in the process of the teaching of communication itself to the students, ${ }^{12}$ communication still lacks studies in which the lecturers indicate how their own communication can be, ${ }^{3}$ especially nonverbal communication and in the teaching of nursing.

The objective proposed for this study was to investigate the nursing lecturers' perception regarding what effective and efficacious nonverbal communication in the classroom is.

\section{METHOD}

This exploratory, descriptive field study, with a qualitative approach, was undertaken in a private university which has four campuses in the city of São Paulo, in three of which there was an Undergraduate Course in Nursing in the morning and the evening periods.

The data were collected in the second semester of 2011, and the university which hosted the study had 18 lecturers on the undergraduate course; all were invited to participate in the study. However, a sample of 11 lecturers, who met the inclusion criteria, was filmed and interviewed, that is, the lecturers invited had to teach at least one course for some of the semesters of the undergraduate course in nursing. The following were excluded from the sample: nurses who provided services for the institution who are not lecturers and nurse lecturers who lectured in other courses apart from nursing.

This research project was approved by the Research Ethics Committee of the School of Nursing of the Universidade de São Paulo (EEUSP), respecting the ethical precepts of research with human beings in line with Resolution 196/96 of the National Health Council, process N. 1.049/2011/ 
CEP-EEUSP, SISNEP CAAE n. 0054.0.196.251-11, having been forwarded to the coordinator of the Nursing Course of the university which hosted the study.

Following approval, the possible subjects/ lecturers were contacted via email, their addresses provided by the coordinator of the Nursing Course. The formal invitation was made through contact via email, and a clear and succinct explanation was also given about the research; the study was also explained by telephone to those subjects who provided a telephone number.

Data was collected in three separate points: the first was the filming of the class, the second, the reproduction of the filmed part of the class for the lecturer to observe his or her own nonverbal performance, and the third, the recorded interview, recorded using a digital recorder (MP3).

Dates were arranged individually with the lecturers who accepted to participate, so that the terms of consent could be signed and the lesson filmed. The data were collected in accordance with the class schedule in the institution, on days and at times in which the courses were taught by the lecturers participating.

Filming is indicated as a technique which documents moments or situations of the universe researched, which is particularly interesting for dealing with planes of image and communication. Video has the role of recording data, as whenever some set of human actions which is complex and difficult to describe comprehensively by a single observer occurs - especially in relation to facial expressions - one obtains more correct judgments when one uses expressions which were filmed for observing. ${ }^{13-15}$

In the first period, about 30 minutes after the beginning of the class, filming was initiated (considering that in the first 30 minutes there is a period of "warming up" in which the lecturer is either still taking a register of the students' names, or is passing on some message, prior to the beginning of the lesson proper). The lecturers were first filmed one by one, during one of their lectures of the course chosen: for approximately 20 minutes uninterruptedly, the camera focused on their upper body, it being considered that most of the nonverbal signals are presented there.

The focus of the study and the film was purely and exclusively the lecturer and, for that, it is worth noting that the person filming was positioned to capture the lecturer alone; the students were with their backs to him and did not appear in the film. An explanation was given to the students regarding the study, its objectives and that they would not appear in the film as they were not the focus of the project at that time.

At the second point, a day was scheduled with each lecturer for the excerpt filmed of their class to be watched with the researcher, who explained to the lecturer that the film could be seen a second time, if it was thought necessary.

At a third point, a formal, semi-structured interview was held, recorded using a digital recorder, as the qualitative interview provides basic data for the undertaking and understanding of the relationships between the social actors and their situation, with the objective of understanding in detail the beliefs, attitudes, values and motivations, in relation to the behaviors of persons in the specific social contexts. ${ }^{16}$

The interview's script of questions was as follows: 1) How did you see yourself in the film?; 2) What did you observe of your nonverbal communication?; and 3) How do you think the appropriate nonverbal communication of a lecturer in the classroom can be?

The accounts obtained through the formal recorded interview, based on the semi-structured script, were transcribed in full and analyzed in the light of content analysis. ${ }^{17}$

\section{RESULTS}

A total of 11 lecturers from the hosting institution participated, with a mean length of time working as lecturers of 18 years, the minimum being seven years and the maximum 29 years. The same micro-expression can have very different meanings in different contexts, ${ }^{18}$ hence of the need to initially describe the context in which the lecturers were filmed.

The environment in which all of the lecturers were filmed was a classroom, with the pupils' desks laid out in the traditional way in rows, it being the case that in two of the three campuses, the desks were very close together, making it difficult for the lecturer to move freely around the classroom and with few options of mobility for any other way of laying out the furniture in the room. Positioned close to a whiteboard, there was a table for the lecturer, which was usually on one side of the room, either the left or the right, depending on the room and opposite to the entrance door to the same. Each lecturer brought a personal computer and used the whiteboard, often for pro- 
jecting slides, via a monitor connected to it. This whiteboard was also used to explain the material.

It is important to clarify that, according to the manager of the Nursing Course at this institution, "the use of the tabard* is optional in the classroom".

Based on the analysis of the lecturers' interviews, two categories appeared, explained as follows: 1) Vision of oneself and 2) Appropriate nonverbal communication for lecturers.

Category 1) 'The vision of oneself' brought answers to the question 1) 'How did you see yourself in the film?' and for question 2) 'What did you observe in your nonverbal communication?' jointly, and so they formed the categories described and presented in figures 1 and 2 .

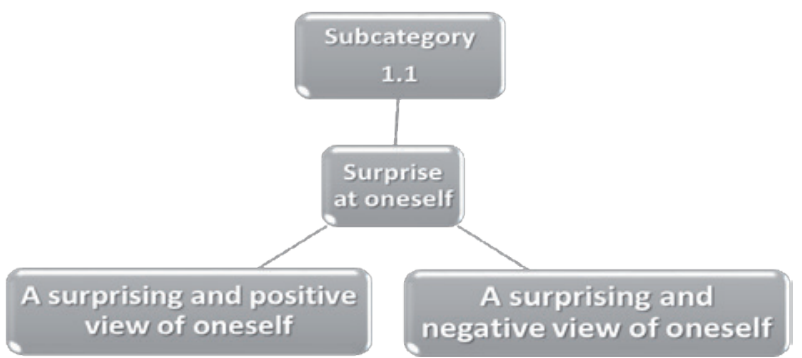

Figure 1 - Representation of category 1) The vision of oneself. São Paulo-SP, 2012

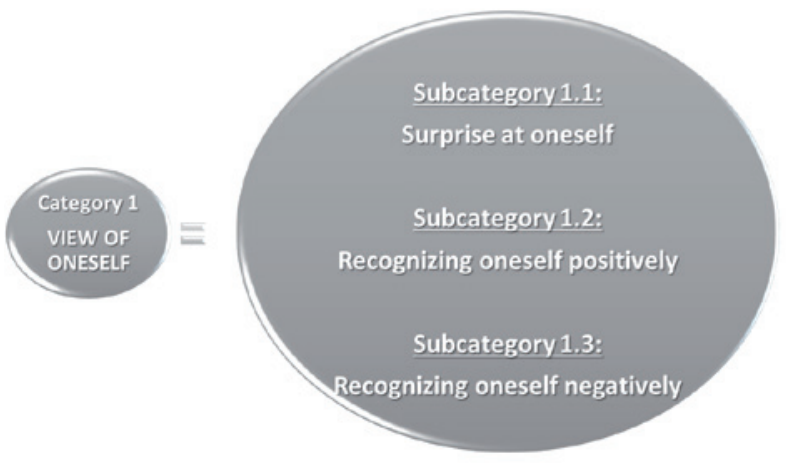

Figure 2 - Representation of subcategory 1.1) Surprise at oneself. São Paulo-SP, 2012

\section{Surprise at oneself}

In this category, the lecturers were surprised when they saw themselves filmed, with some having surprise which depicted a positive view of themselves (Surprising and positive view of oneself) while others had a negative view of themselves (Surprising and negative view of oneself).

Examples of lecturers' accounts, which are most representative and which best illustrate each one of the subcategories follow below. All the interviewees who presented accounts belonging to each of the categories are listed in brackets.

\section{Surprising and positive view of oneself (E1 and E9)}

In the film, I saw myself with a fairly technical posture [...] Especially due to the use of the tabard and $[. .$.$] , more natural than I thought I would be. I thought$ it would be stranger to see myself on the film (E1).

\section{Surprising and negative view of oneself (E2, E5 and E11)}

[...] God, I found myself too serious [...] I thought I was happier, giving lessons [...]. My facial expression is very serious, very incisive, really strict [...]. My tone of voice, less so. And I thought I was a little taller, you know? [...] But my posture, posture of an old lady... [laughs]. [...] I thought I looked old, fat. I know I'm fat, but I thought I was an old fat woman... One of those professors who is a curmudgeonly old bag, you know? [...] (E2).

\section{Recognizing oneself positively}

In this category, the lecturers referred to themselves performing well in giving the class, as expected or imagined, and this did not surprise them. Besides the example of the most representative account from a lecturer, we also list - between brackets - the interviewees whose accounts belong to each one of the categories (E3, E4, E5, E6, E7, $\mathrm{E} 8$, and E10).

I saw myself adequately. I could perceive that I have a firm glance, I can manage to communicate in a way that I consider effective with the students. At the same time, however, if I have a punitive glare, I am very incisive. So, I managed to perceive that..., that it is satisfactory. Although I think that I have to take care with this issue, and, maybe, be incisive in some issues which perhaps the other does not consider so important (E6).

* It is common in Brazil for teachers and lecturers to wear a simple tabard. Translator's note. 


\section{Recognizing oneself negatively}

In this category, there was one lecturer who recognized himself as having a performance which raised a negative aspect in the provision of his class, different from the performance expected or imagined by him and that this did not surprise him. Below is an excerpt of his account:

[...] Basically what I said in terms of posture, you know? My posture is very rigid... I walk in a rigid way. Everybody says that. I walk rigidly. My body is not relaxed. I'm not relaxed. I am... rigid, not rigid in terms of expression, but actually physically, you know? Rigid, hard, I am not relaxed, I'm really not a person who relaxes, you know? That person who is more relaxed, more laid back. Maybe I am when I play with the students. [...] the people who know me, family members, say: 'You walk, your walk is rigid'. I found myself rigid when teaching [...] (E2).

Category 2) Appropriate nonverbal communication for lecturers, responds, in its turn, to question 3) How do you think that a lecturer's appropriate nonverbal communication in the classroom should be? Forming three subcategories, represented in figure 3.

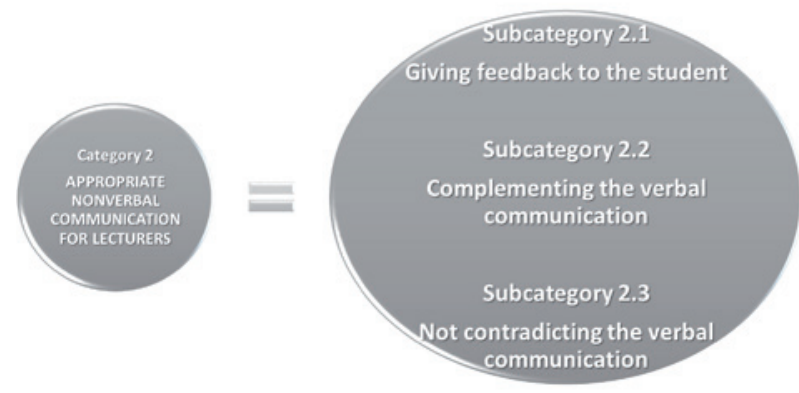

Figure 3 - Representation of category 2) Appropriate nonverbal communication for lecturers. São Paulo-SP, 2012

\section{Giving feedback to the student}

In this subcategory, the lecturers referred to the behaviors of encouragement, involvement and motivation for the student, as in the account below, as well as the accounts found in E11 and in E5.

I think that what has to be, is..., I have to know who my receptor is and how to pass this message on. So, today, we have students who differ from each other widely. We have hard-working students, tired students..., So I have to try to involve, motivate the students in this content that I am applying. I think that one good strategy is, for example, for the students to feel important in the process. So I try to involve them, to get to know them, to call them by their name, even to touch them, to play, to make the lesson pleasant [...] (E6).

\section{Complementing the verbal communication}

In this subcategory, the lecturers mentioned behaviors which complement speech, that is, the verbal communication, as can be observed in the accounts of E1, E2, E4, E8, E9, E10 and E3, represented below:

[...] It is a way of communicating which I think is part of all of our lives, because we don't communicate just through speaking. I think that it complements, and is a type of communication. Which will pass on... the same message, or a very similar message, with..., with the expression, you know? With the nonverbal communication. I think that is what it is! (E3).

\section{Not contradicting the verbal communication}

This category, on the other hand, was related to times in which the lecturer said something, but his nonverbal communication contradicted his words, as in the example of E4, below, besides E5 and E7.

[...] I can't not use [non] verbal communication. I think that nonverbal communication is part of communication. So sometimes you say something wrong, which you end up correcting nonverbally. So much so, that often, I see myself saying one thing, but expressing another and the students [...] It's like this, I see from their expressions: 'God....' 'you know...' 'it was the opposite!', and we correct ourselves. So I think that [non] verbal communication is fundamental. I think that there is no communication without it... Only verbal [...] (E4).

\section{DISCUSSION}

The surprise perceived by some lecturers at themselves in the film - positive or negative - may be related to the phenomena of "Experiencing

\footnotetext{
* In this part of the recording we heard the lecturer say: "I can't not use verbal communication", however, evaluating the context, and with the aim of not invalidating (the account), we added the word "non" between parentheses, such that the phrase could have the meaning intended by the lecturer.
} 
communication as discovery". In this phenomenon, the condition of being concerned is the cause responsible for the alterations also perceived by nurses in continuing education at the beginning of their film, as it may also be, as already expressed, the condition responsible for the changes in the nonverbal dimensions/aspects perceived by some lecturers. ${ }^{9}$

Regarding subcategories 1.2) Recognizing oneself positively and 1.3) Recognizing oneself negatively, it is important to note the extent to which it is not easy for us to recognize ourselves ${ }^{19}$ and that, even with all this difficulty, self-knowledge, which is a constant learning, is a condition sine qua non for effective communication with somebody.

In the interviews recorded, it became clear that in the View of themselves, the professors could identify different aspects of the nonverbal communication, when they cited examples, in their accounts, principally of the kinesthetic dimension of their nonverbal communication, although without much specificity.

The lecturers also verbalized the importance of nonverbal communication and its influence on the interpersonal relationship with the students both positively and negatively, as they were able to give isolated examples, related to other dimensions of nonverbal communications, even without being able to name some technically, as in the examples of the dimensions:

- Tacesics - E6 [...] I try to interact with the students, to touch them [...];

- Proxemic - E6 [...] I could see in the filming that I move towards the student, so, I move towards them to try to get closer, to try to get them to receive the message adequately [...];

- Paraverbal - E7 [...] It is just that I didn't like when I explained and laughed at some points..., At some points, you know? So, for somebody on the outside it seems like I am laughing at the psychiatric patient, and that's not it!... you know? So, I didn't like that part when... I was laughing, I didn't like that. I thought that my laughter was inappropriate in the class, during the class;

- Characteristics of the environment - E8 [...] what I even put in the evaluation, something which I missed most was the closeness with them, but... There are some..., some..., Some variables there, which also didn't help, you know? For example, the way the room is laid out and how the spaces are which we have in the room, the furniture. But, it is... I usually work close to them [...]. I can't have a relationship which is not affective with people [...].

The kinesthetic dimension seems to be the nonverbal dimension identified most, as it deals with body language, that is, the bodily gestures and facial expressions. In relation to the kinesthetic dimension, some members of the Postgraduate Program of the USP, in participating in the course "Communication in adult health: interaction of verbal and nonverbal language in the interpersonal relationships", undertook a study which was part of the activities of the course in question, for the presentation of a seminar on "Kinesics: the language of the body" ${ }^{20}$

In this study, ${ }^{20}$ the students requested the other 20 postgraduate students/colleagues, present at the presentation seminar on Kinesics, that they should respond in writing, prior to the theoretical explanation of the content: "What do you know about body language?". As results, five categories appeared (concept, function, importance, meaning and forms of manifestation of body language), in which the postgraduate students valued the body language, stating it to be a complex form of interpersonal interaction of which we have little awareness, its happening, sometimes, without our being able to control it. They added that through this language we transmit feelings, emotions and messages, with meanings influenced by the context. The authors finished by mentioning that knowledge of body language broadens our professional perception, being one more instrument for improving the quality of the nursing care.

In the understanding of what appropriate nonverbal communication for lecturers is, they discuss the importance of feedback for the student, corroborating a recent study on feedback, which considers it to be fundamental for us to be able to maintain a high educational level and higher level of clinical assistance in the area of health. ${ }^{21}$

In another study on nursing lecturers' communicative competency, ${ }^{12}$ one of the categories found by the authors was the lecturer's awareness of the verbal and nonverbal communication and interaction, it being the case that this awareness involves being alert to the other in order to perceive what he wishes to communicate and to confirm whether the communicative intention was transmitted or not, that is, to give and receive feedback so as, thus, to ascertain whether the objectives of the lessons are being achieved, or, further, if the students have doubts, or whether they are interested in the lesson. 
Still on the subject of what appropriate nonverbal communication is for the lecturers, the following subcategories appeared: Complementing the verbal communication and Not contradicting the verbal communication, which are two of the four functions of nonverbal communication ${ }^{1}$ (the others being the substitution of the verbal communication, and the demonstration of feelings). When used well, these categories qualify still further the interaction between the lecturer and the student, improving the effectiveness and the efficacy of the nonverbal communication in the classroom.

In relation to Complementing the verbal communication, the use of the voice appropriately, that is, to create a tone of conversation with the room, rather than a tone of discourse, can be more efficacious. ${ }^{3}$ Regarding Not contradicting the verbal communication, honesty with the audience/classroom was cited as being extremely important in facilitating learning, ${ }^{3}$ as a lecturer who demonstrates coherence between his words and his attitude, that is, coherence between his verbal and nonverbal communication or, further, a true lecturer awakens the respect of his students, opening doors for a true bond between both.

Making nonverbal communication effective/ efficacious requires - besides specific knowledges in communication - dedication to learning and reflection on the issue, training for decodifying appropriately the signals emitted by the interlocutors of the relationship, ability to observe the other and oneself, ${ }^{1,12,19}$ and motivation, that is the will, to do so.

We have corroborated here the findings of some educators ${ }^{4}$ regarding the lecturer's awareness in relation to his role as educator, relativizing his knowledge with humility and remembering the need to understand the issues of communication, especially nonverbal communication which brings quality to the relationships as - as humans - we are the expression of communication itself.

For other educators, ${ }^{5}$ knowledge is a cultural construction; it remind us, therefore, that in this cultural construction, the lecturer's appropriate nonverbal communication can bring positive influences.

\section{FINAL CONSIDERATIONS}

The perception which the lecturers researched have of their own nonverbal communication is that, in general, it is good, it is what they expected and it is adequate - that is, it is, generally speaking, acceptable. The majority perceives them- selves positively, without surprising themselves. The lecturers who perceive themselves negatively mentioned examples in their nonverbal communication related to their rigid, strict posture, their facial expression of disappointment with the students, and the inappropriate interpersonal distance, considering the furniture as barriers.

It is important, however, to consider that when they watched the film of their class, the researcher observed facial micro-expressions of mild surprise (through a rapid and subtle raising of eyebrows) in some lecturers, or, then, noted that they made brief comments about the discovery of seeing themselves filmed, although some had not mentioned surprise during the recording of the interview.

In relation to effective and efficacious nonverbal communication, the lecturers considered that it is that which offers feedback to students, bringing them closer to the professor; which calls attention to the content instead of to the lecturer, with gestures which encourage student participation, bringing them closer; it is that communication which complements verbal communication with expressions, gestures and looks which reinforce what is spoken and valorize the students; it is communication which involves and motivates the students and makes them feel important in the teaching-learning process; it is communication which pleases and which makes use of affective touch between lecturer and student.

It is important to highlight these limitations of the study in relation to its regional character, as it was restricted to a single university, indicating necessity for replicating the same in other contexts; but in spite of these restrictions it is possible to assert that, based on the lecturer's perception regarding the appropriate use of his own nonverbal communication, there is a qualification of the interpersonal relationships for the students in the classroom, reducing misunderstandings, reducing noises in the communication between the lecturer and student, and - possibly - strengthening the learning of the student body.

\section{REFERENCES}

1. Silva MJP. Comunicação tem remédio: a comunicação nas relações interpessoais em saúde. $10^{\text {a.ed. São }}$ Paulo (SP): Loyola; 2012.

2. Sgariboldi AR, Puggina ACG, Silva MJP da. Análise da percepção dos professores em relação aos sentimentos dos alunos em sala de aula. Rev Esc Enferm USP. 2011 Out; 45(5):1206-12. 
3. Longo A, Tierney C. Presentation skills for the nurse educator. J Nurses Staff Dev. 2012 Jan-Fev; 28(1):16-23.

4. Freire P. Educação e mudança. $34^{\mathrm{a}}$ ed. Rio de Janeiro (RJ): Paz e Terra; 2011.

5. Cortella MS. A escola e o conhecimento: fundamentos epistemológicos e políticos. $14^{\mathrm{a}}$ ed. São Paulo (SP): Cortez: Instituto Paulo Freire; 2011.

6. Bordenave JD, Pereira AM. Estratégias de ensinoaprendizagem. $29^{\mathrm{a}}$ ed. Petrópolis (RJ): Vozes; 2008.

7. Bosquetti LS, Braga EM. Reações comunicativas dos alunos de enfermagem frente ao primeiro estágio curricular. Rev Esc Enferm USP. 2008 Dez;42(4):6906.

8. Husebø SE, Rystedt H, Friberg F. Educating for teamwork - nursing students' coordination in simulated cardiac arrest situations. J Adv Nurs. 2011 Oct; 67(10):2239-55.

9. Silva MJP, Pereira LL. Vivenciando a comunicação como descoberta. Mundo da Saúde. 2000; 24(5):33342.

10. Reilly JR, Gallagher-Lepak S, Killion C. "Me and my computer": emotional factors in online learning. Nurs Educ Perspect. 2012 Mar-Abr; 33(2):100-5.

11. Riera JRM, Cibanal JL, Mora MJP. Using role playing in the integration of knowledge in the teachinglearning process in nursing: assessment of students. Texto Contexto Enferm. [online]. 2010 [acesso 21 Jun 2013]; 19(4):618-26. Disponível em: http://www. scielo.br/scielo.php?script=sci_arttext\&pid $=$ S010407072010000400003\&lng=en\&nrm=iso

12. Braga EM, Silva MJP da. Comunicação competente visão de enfermeiros especialistas em comunicação. Acta Paul Enferm [online]. 2007 [acesso 5 Fev
2013]; 20(4):410-4. Disponível em: http://www. scielo.br/scielo.php?script=sci_arttext\&pid=S010321002007000400004\&lng=en

13. Loizos P. Vídeo, filme e fotografias como documentos de pesquisa. In: Bauer MW, Gaskell G, editores. Pesquisa qualitativa com texto, imagem e som. $11^{\text {a }}$ ed. Petrópolis (RJ): Vozes; 2011. p. 137-55.

14. Minayo MCS. O desafio do conhecimento: pesquisa qualitativa em saúde. 12a ed. São Paulo (SP): Hucitec; 2010.

15. Knapp ML, Hall JA. Nonverbal communication in human interaction. Boston (US): Wadsworth Cengage Learning; 2010.

16. Gaskell G. Entrevistas individuais e grupais. In: Bauer MW, Gaskell G, editores. Pesquisa qualitativa com texto, imagem e som. $11^{\text {a }}$ ed. Petrópolis (RJ): Vozes; 2011. p. 64-89.

17. Bardin L. Análise de conteúdo. Lisboa (PT): Edições 70; 2009.

18. Ekman P. A linguagem das emoções: revolucione sua comunicação e seus relacionamentos reconhecendo todas as expressões das pessoas ao redor. São Paulo (SP): Lua de Papel; 2011.

19. Wood P. Os segredos da comunicação interpessoal: usando a arte da comunicação para melhorar a sua vida e a dos outros. Rio de Janeiro (RJ): Bertrand Brasil; 2007.

20. Silva LMG, Brasil VV, Guimarães HCQCP, Savonitti BHRA, Silva MJP. Comunicação não verbal: reflexões acerca da linguagem corporal. Rev LatinoAm Enfermagem. 2000 Ago; 8(4):52-8.

21. McKinley RK, Williams V, Stephenson C. Teachers: improving the content of feedback. The Clinical Teacher. 2010 Set; 7(3):161-6. 